\title{
The Protective Effect of Aqueous Seed Extract of Parkia Biglobosa on the Anterior Pituitary Gland of Wistar Rat
}

\author{
Kebe E Obeten ${ }^{1 *}$ Gabriel U Udo-Afah ${ }^{2}$, Ettah E Nkanu ${ }^{1 *}$ and Ikwagu S Chidinma ${ }^{1}$ \\ ${ }^{1}$ Department of Anatomy and Forensic Science, Cross River University of Technology, Nigeria \\ ${ }^{2}$ Department of Anatomy University of Calabar, Nigeria
}

*Corresponding author: Kebe E Obeten, Department of Anatomy and Forensic Science, Cross River University of

Technology, Nigeria

\section{ARTICLE INFO}

Received: 幽 August 10, 2020

Published: 幽 August 19, 2020

Citation: Kebe E O, Gabriel U U, Ettah E N and Ikwagu S C. The Protective Effect of Aqueous Seed Extract of Parkia Biglobosa on the Anterior Pituitary Gland of Wistar Rat. Biomed J Sci \& Tech Res 29(4)-2020. BJSTR. MS.ID.004837.

Abbreviations: PAS: Period Acid Schiff's; SPSS: Statistical Package for Social Sciences; TSH: Thyroid-Stimulating Hormone; LH: Luteinizing Hormone; FSH: Follicle Stimulating Hormone; ACTH: Adrenocorticotropic Hormone; Prl: Prolactin; GH: Growth Hormone; ROS: Reactive Oxygen Species

\section{ABSTRACT}

This study was aimed at investigating the neurotoxicity effect of aqueous seed extract of Parkia biglobosa on the anterior pituitary gland of adult Wistar rats. Twenty one adult male wistar rats weighing between 90-130g were assigned randomly into three groups; group A were fed with normal rat chew and water, group B which served as low dose were administered with $300 \mathrm{mg} / \mathrm{kgBw}$ of Parkia biglobosa seed extract, while group $\mathrm{C}$ were administered with $600 \mathrm{mg} / \mathrm{kgBw}$ seed extract of Parkia biglobosa. Administration was done orally for four weeks Twenty-four hours after the last administration the animals in all groups were sacrifice under cervical dislocation, and the anterior pituitary was harvested and preserved in $10 \%$ buffer ssformalin followed by H\&E staining. Morphological result revealed a dose dependent significant increase $(\mathrm{p}<0.05)$ in the weights of the treated animals. The result of the histology showed increased cell reproduction in the low $\{300 \mathrm{mg} / \mathrm{kgbwt}\}$ and high $\{600 \mathrm{mg} / \mathrm{kgbwt}\}$ dose groups which indicate reduction in the activities of reactive oxygen species. Histochemistry studies, usingperiodic acid Schiff $\{$ PAS $\}$ revealed marked cells production in the treated groups, indicating positive PAS reaction, this could suggest that aqueous seed extract of Parkia biglobosa have anti-toxicity and antioxidant properties, which may help to prevent cellular damage caused by reactive oxygen species in the pituitary glands.

Keywords: Parkia Biglobosa; Neurotoxicity; Anterior Pituitary; Anti- Toxicity; Histochemistry

\section{Introduction}

Green plants obtain most of their energy from sunlight via photosynthesis by primary chloroplasts that are derived from endosymbiosis with cyanobacteria. Their chloroplast contains chlorophylls $\mathrm{a}$ and $\mathrm{b}$, which gives them their green color [1]. There are about 320 thousand species of plants, of which the great majority, some 260-290, thousand are seed plants. Green plants provide a substantial proportion of the World's molecular oxygen and are the basis of most of Earth's ecosystems, especially on land [2]. The term plant generally implies the possession of the following traits: multicellularity, possession of cell walls containing cellulose, and the ability to carry out photosynthesis with primary chloroplast [3]. Parkia Biglobosa, also known as the African locust bean (West African names: néré, dodongba, netetou , sumbala or iru ) is a perennial deciduous tree of the family Fabaceae [4]. It is found in a wide range of environments in Africa and is primarily grown for its pods that contain both a sweet pulp and valuable seeds. Where the tree is grown, the crushing and fermenting of these seeds constitutes an important economic activity [5]. Various parts of the locust bean tree are used for medicinal purposes [6,7]. As a standing tree, locust bean may have a positive effect on the yield of other nearby crops [8]. Parkia biglobosa is a dicotyledonous 
angiosperm belonging to the family Fabaceae (Caesalpinioideae Mimosoid clade). It is categorized under spermatophytes, vascular plants [8]. It is a tree that grows to between 7 and 20 metres high, in some cases up to 30 metres [9]. The tree is a fire-resistant heliophyte characterized by a thick dark gray-brown bark [7]. The pods of the tree, commonly referred to as locust beans, are pink in the beginning and turn dark brown when fully mature. They are 30-40 centimetres long on average, with some reaching lengths of about 45 centimetres. Each pod can contain up to 30 seeds; the seeds are embedded in a sweet, powdery yellow pulp [9].

The anterior pituitary is the major organ of the endocrine system and it is also called adenohypophysis or pars anterior, it is the glandular lobe that together with the posterior lobe or the neurohypophysis makes the pituitary gland (hypophysis). The anterior pituitary is derived from the ectoderm, more specifically from the Rathke's pouch, part of the developing hard palate in the embryo. The pouch eventually loses its connection with the pharynx, giving rise to the anterior pituitary [10]. The anterior wall of Rathke's pouch proliferates, filling most of the pouch to form the pars distalis and the pars tuberalis. The posterior wall of the anterior pituitary forms the pars intermedia. Its formation from the soft tissues of the upper palate contrast with the posterior pituitary, which originates from neuroectoderm [11]. In cognitive function; the anterior pituitary gland produces the following hormones and releases them into the bloodstream: adrenocorticotropic hormone, which stimulates the adrenal glands to secrete steroid hormones, principally cortisol. Growth hormone, which regulates growth, metabolism and body composition [12]. The use of Parkia biglobosa as herbal medicaments in African countries and the reports on the toxicity of the plant further show that the plant is non-toxic to humans [12] but the bark and the pods of the same plant contain parkine and equally have piscicidal property [12]. The extracts of raw Parkia biglobosa seed exhibited termiticide activity [13].

The functions of the male reproductive organs are controlled by hormones secreted by the anterior pituitary gland. Testes are controlled by Gonadotrophs which travel via the bloodstream to the testes [14]. Release of gonadotrophs from the pituitary is also absent in Kallmann's Syndrome, a rare genetic syndrome frequently associated with absence of the sense of smell (anosmia) [15]. In kallmann's Syndrome the hypothalamus fails to release GnRH. The lack of stimulation of the pituitary by GnRH means that the pituitary in turn does not release LH and FSH [16]. The production and release of FSH is regulated by the levels of a number of circulating hormones released by the ovaries and testes [17].

\section{Materials and Methods}

\section{Preparation of Aqueous Extract of Parkia Biglobosa (Seed)}

Fresh Parkia Biglobosa pods were gotten from a farm at Makurdi in Benue state Nigeria. The pods were open and the seeds removed, fermented and well dried. After drying, they were blended to a fine powder. The powder was percolated in $100 \mathrm{ml}$ of distilled water for 72hours (3days) and filtered using watmann filter paper [18]. The filtrate was evaporated to dryness at $45 \mathrm{c}$, giving rise to an oil crude extract. This was stored in refrigerator until required for use.

\section{Experimental Animals}

Twenty one (21) adult wistar rats weighing between 90$130 \mathrm{~g}$ were obtained from the animal house of Human Anatomy Department, Faculty of Basic Medical Sciences, Cross River University of Technology, Okuku Campus. The animals were fed with commercial feed and water ad libitum for four (4) weeks [19].

\section{Experimental Design and Procedure}

Group A (CONTROL) animals received water and normal saline only.

Group B (LOW DOSE) animals received aqueous extract of Parkia biglobosa seeds at a dose of $300 \mathrm{mg} / \mathrm{kgBw}$

Group C (HIGH DOSE) animals received aqueous extract of Parkia biglobosa seeds at a dose of $600 \mathrm{mg} / \mathrm{kgBw}$ orally by means of oral cannula once daily for 30days [20].

\section{Administration of Aqueous Extract of Parkia Biglobosa (SEED)}

From the locust bean extract, the stock solution was prepared by dissolving $0.5 \mathrm{~g}$ of the extract in $10 \mathrm{ml}$ of distilled water [17]. Then the different dosage was used to administer base on the body weight of the animals [21]. Therefore, every $0.5 \mathrm{ml}$ of the extract administered contain $600 \mathrm{mg} / \mathrm{kgbwt}$ of the extract for the high dose while $0.3 \mathrm{ml}$ of it contained $300 \mathrm{mg} / \mathrm{kgbwt}$ for the low dose but animals received according to their body weights and the control group were given normal feeds and distilled water. The extracts were administered orally once every day for thirty (30) days [22].

\section{Termination of Experiment}

At the end of the four weeks, all the animals in the control and treated groups were sacrificed using cervical dislocation [22]. The anterior pituitary gland of these animals were removed, preserved in $10 \%$ formal saline [23], and processed for histological studies [24].

\section{Histological Analysis}

The anterior pituitary of the animals were removed and preserved in labeled bottles containing $10 \%$ buffered formalin. There were allowed to stand for 72 hours to achieve good tissue penetration and effective fixation. After this [25], there were placed in ascending grades of ethanol each lasting for one hour followed by 95\% ethanol and then absolute alcohol for the same duration [26]. Following dehydration, the tissues were cleared in three changes 
of xylene each lasting for fifteen minutes. Impregnation in molten paraffin was at 58c was carried out overnight and the following morning [27], the tissue were embedded in wax to form block were trimmed and section at $5 \mathrm{u}$ thickness using the rotator microtome [28].

The sections were floated [29] in warm water (280c) and then taken up on albumenized glass slides [30]. They were air-dried and stained using Period Acid Schiff's (PAS) (Mc Manus, 1946) staining methods for tissue blocks were section at $5 \mu$ with rotary microtome [31]. There were dewaxed in xylene for 2 minutes per two changes. Xylene was cleared in $95 \%$ alcohol for 1 minutes per two changes [32] and then in $70 \%$ alcohol for another minute [33]. The sections were then hydrated in running up water for 15 minutes differentiated in $1 \%$ alcohol for 5 -10seconds [34]. The sections were washed well in running tap water until the sections turned blue (Figure 1). There were thereafter counterstained with $1 \%$ alcohol-eosin for 1 minute [35], followed by rapid dehydration through ascending grades of alcohol cleared in xylene and mounted with DPX mounting [36]. Stain section were viewed under a light microscope and photographed [37].

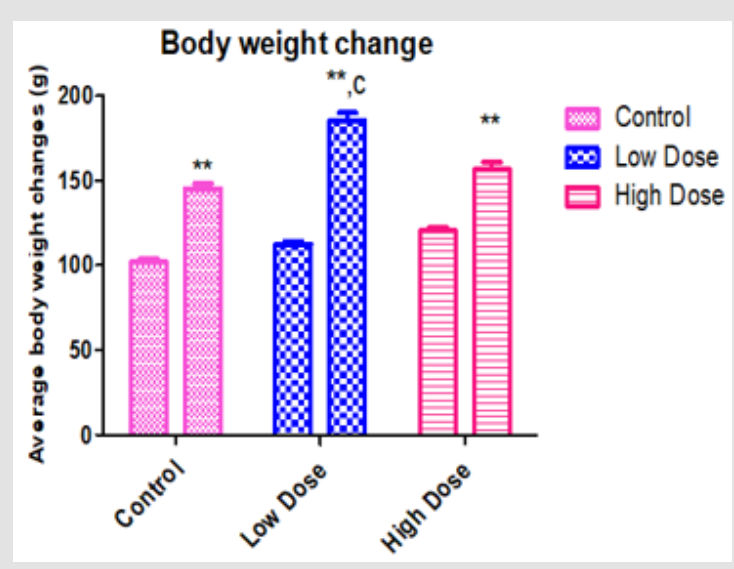

Figure 1: Showing effect of Parkia biglobosa extract on average body weight changes in Wistar rats.

Note: Values are expressed in Mean \pm SEM $n=5, * * *=p<0.01$ vs control, $c=p<0.01$ vs High dose.

Table 1: Morphological observation of body weight.Statistical Analysis

\begin{tabular}{|c|c|c|}
\hline \multicolumn{3}{|c|}{ BODY WEIGHTS } \\
\hline GROUPS & INITIAL & FINAL \\
\hline Control & $101.8 \pm 2.273$ & $145.0 \pm 3.225^{* *}$ \\
\hline Low dose & $112.5 \pm 1.677$ & $185.2 \pm 4.790^{* *}$ \\
\hline High dose & $120.5 \pm 1.891$ & $156.6 \pm 4.226^{* *}$ \\
\hline
\end{tabular}

Note: Values are presented as Mean \pm SEM

**= significantly different from the initial body weight at $\mathrm{p}<0.01$

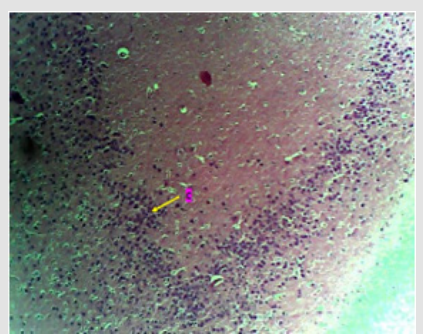

Figure 1A: Photomicrograph showing the control group of the anterior pituitary gland with many cells (C) appearing normal. (H \& E. X10)

Statistical analysis was done using Statistical Package for Social Sciences (SPSS) VERSION 16 Chicago Inc. One way ANOVA, followed by Bonferroni's Multiple Data comparison Test was used to perform the analysis [38] (Histology Figures 1A \& 1B). Result of descriptive statistics of the experimental data was presented as mean standard error of the mean (mean + SEM) [39]. Paired simple T-Test were considered statistically significant at $\mathrm{P}<0.05$ [40]. Morphological observation from the [41] study shows an observable significant increase in the final mean body weight [42] when compared with the initial body weight [43]. The final body weight of the control animals $(145.0 \pm 2.273)$ was significantly $(p<0.01)$ higher than its initial body weight (101.8 \pm 2.273$)$ [44]. However, the mean final body weight of the low dose group $(185.2 \pm 4.790)$ and high dose group $(156.6 \pm 4.226)$ were significantly $(\mathrm{p}<0.01)$ higher than their [45] initial body weights $(112.5 \pm 1.677)$ and $(120.5 \pm 1.891)$. respectively (Table 1) [46].

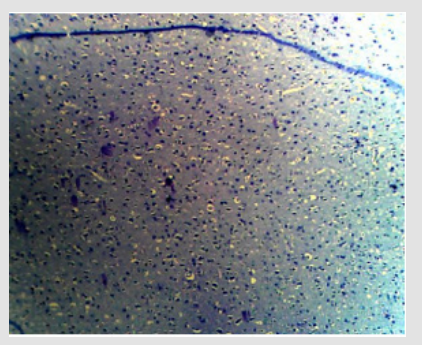

Figure 1B: Photomicrograph showing the control group of the anterior pituitary gland with many cells (C) appearing normal. (PAS X10) 


\section{Discussion}

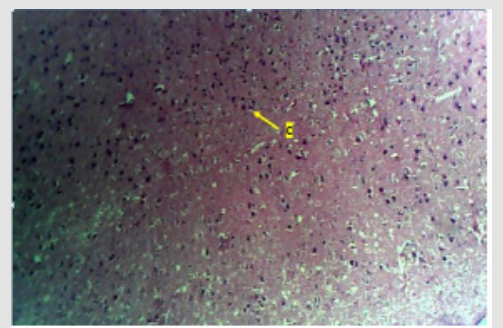

Figure 2A: Photomicrograph of low dose of the anterior pituitary showing the cells $(\mathrm{C})$ that make up the region. Areas appear normal. (H \& E. X10)

It still remains that the main recourse for a large majority of people for treating health problems is medicinal plants [47]. Approximately $80 \%$ of the population of the world depends according to the World Health Organization on traditional medicine, mostly herbal remedies [48], for their primary health care needs [49]. Therefore, the beneficial plant was referred to as 'medicinal plant' [50]. Interestingly, the use of herbal medicine was double to triple fold more than conventional drugs and $80 \%$ of the world population especially in developing countries still depend on plant-derived medicines for maintenance of health and treatment of disease [51].The anterior pituitary, or denohypophysis, plays a central role in the regulation of endocrine function through for the production and release of tropic hormones [52]. The function of the anterior pituitary [53], and thereby the production of tropic hormones [54], is under hypothalamic regulation by the hypophysiotropic neuropeptides releases in the median eminence [55]. The tropic hormones produced by the anterior pituitary are released into the systemic circulation, from where they reach their target organs to produce a physiologic response, most frequently involving the release of a target organ hormone (Histology Figures $2 \mathrm{~A} \& 2 \mathrm{~B})$. The hormones produced by the target organs affect anterior pituitary function as well as the release of hypophysiotropic neuropeptides, maintaining an integrated feedback control system of endocrine function [34]. Anterior pituitary hormones, target organs, and physiologic effects. Thyroid-Stimulating Hormone (TSH) stimulates the thyroid gland to produce nd release thyroid hormones that regulate growth, differentiation, and energy balance. Luteinizing Hormone (LH) and Follicle Stimulating Hormone (FSH) stimulates gonadal production of sex steroids, which mediate reproductive function and behavior. Adrenocorticotropic Hormone (ACTH) stimulates the adrenal glands to produce steroid hormones, which regulate water and sodium balance, inflammation [56], and metabolism. Prolactin (Prl) stimulates breast development and milk production. Growth Hormone (GH) [57] exerts direct effects on tissue growth and differentiation and indirect effects through the stimulation of insulin- like growth factor 1 production [58], which mediates some of the growth and differentiation effects of GH [59].

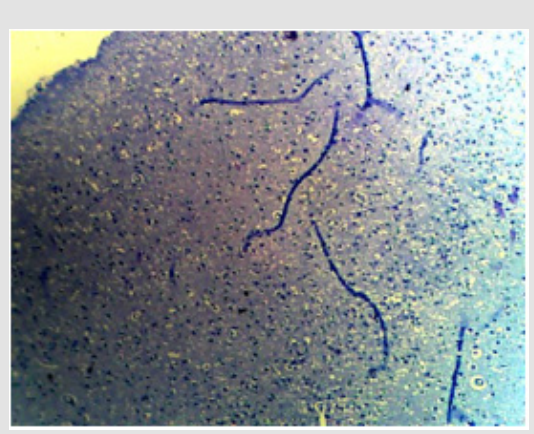

Figure 2B: Photomicrograph of low dose of the anterior pituitary showing marked cells (C). (PAS X10)

In this study [60], Parkia biglobosa had clearly demonstrated its positive influence as increase weight gain was observed after values gotten from the assay after administration [61] were compared to values of the initial body weight of experimental animals before administration [62]. This may be due to the presence of high nutritional component of the extract, such as proteins) [63], which main primary function is to increase cell productivity [64], which aids in the repair of warn out tissues and replacement of death cells thereby increasing weight gain [65] which corresponds with [51]. Whereas, weight gain without increased calorie rich food intake might be a symptom of serious medical condition, according to the observed trend in the percentage change in weight of the rats was an indication that the rats were able to recover from any nutrient deficiency suffered during the growing phase (Histology Figures $3 \mathrm{~A}$ \& 3B). This agreed with the report of the increase in weight gain observed by the administration of this extract is not traceable to any future or immediate risk of obesity this is in line with other reports on African locust bean seeds carried out in southern part of Nigeria and the analytical data in this study revealed that Parkia biglobosa seeds seemed to be a potential source of protein and essential amino acids [66]. The result also gives useful information about the use of Parkia biglobosa for further exploration to cope with increasing demand of protein. The seeds in particular have attractive amino acid profiles.

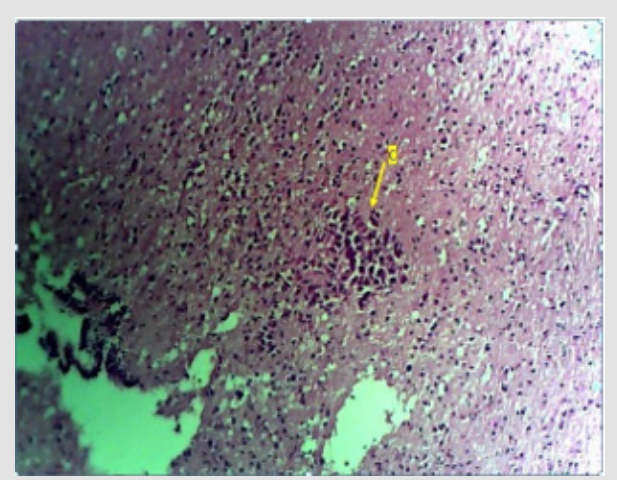

Figure 3A: Photomicrograph of the High Dose group of the anterior pituitary showing many cells (C) appearing normal. (H \& E. X10) 


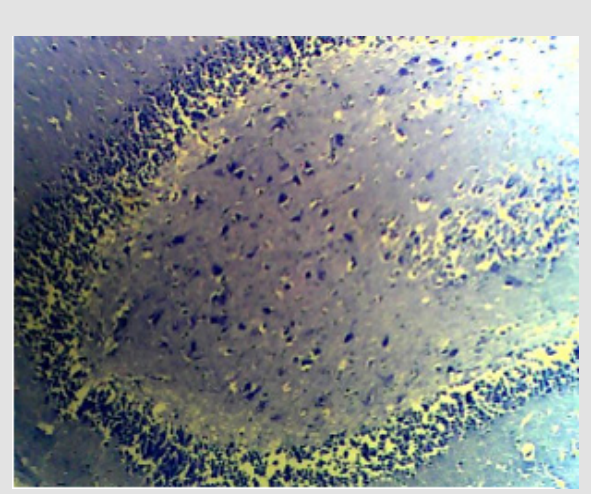

Figure 3B: Photomicrograph of the High Dose group of the anterior pituitary showing increased marked cells (C) appearing normal. (PAS X10)

The increase cells activities of the pituitary gland as observed in this study is in line with previous studies carried out by [67] The likely effect of the increase cell reproduction in the pituitary gland may be due to the anti toxicity and antioxidants properties isolated from the crude extract that is known from previous studies on the photochemical constituents of Parkia biglobosa this antioxidants works by reducing or lowering the activities of Reactive Oxygen Species (ROS), which if allowed in the body destroys the cells of the pituitary gland, thereby causing impaired function of the gland [2]. This is an indication that Parkia biglobosa has a positive effect on the pituitary gland [68].

\section{Conclusion}

From the results obtained in this study, it could be concluded that aqueous extract of Parkia biglobosa has no adverse effect in the anterior pituitary gland, thus, intake of aqueous extract of Parkia biglobosa could cause increase in weight gain and also increase cells activities [69].

\section{References}

1. Abalaka SE, Auta J (2010) Toxic Effects of Aqueous and Ethanol Extracts of Parkia biglobosa Pods on Clarias gariepinus Adults. World Journal of Biological Research 003(1): 9-17.

2. Abioye E, Akinpelu D, Aiyegoro O, Adegboye M, Oni M, et al. (2013) Preliminary phytochemical screening and antibacterial properties of crude stem bark extracts and fractions of Parkia biglobosa (Jacq.) Molecules 18(7): 8459-8499.

3. Adetutu A, Morgan W, Corcoran O (2011) Ethnopharmacological survey and in vitro evaluation of wound-healing plants used in South-western Nigeria. J Ethnopharmacol 137(1): 50-56.

4. Adjanohoun E, Adjakidje V, Ahyi MRA, Ake Assi L, Akoegninou A, et al. (1989) Contribution aux études ethnobotaniques et floristiques en République populaire du Bénin. Médecine Traditionnelle et pharmacopée. Agence de Coopération Culturelle et Technique, Paris p. 895.

5. Agra MF, Freitas PF, Barbosa-Filho JM (2007) Synopsis of the plants known as medicinal and poisonous in Northeast of Brazil. Rev Bras Farmacogn 17: 114-140.

6. Alberts B, Johnson A, Lewis J, Raff M, Roberts K, et al. (2002) Molecular Biology of the Cell ( $4^{\text {th }}$ Edn.). New York and London: Garland Science.
7. Alberts B, Johnson A, Lewis J, Raff M, Roberts K, et al. (2014) Molecular Biology of the Cell ( $6^{\text {th }}$ Edn.). Garland. p. Chapter 4: DNA, Chromosomes and Genomes.

8. Anderson DM (2000) Dorland's illustrated medical dictionary $\left(29^{\text {th }}\right.$ Edn).

9. Becker B, Marin B (2009) Streptophyte algae and the origin of embryophytes. Annals of Botany 103(7): 999-1004.

10. Bevan CWL, Ekong DEU, Obasi ME (1966) West African timbers. XIII. Extracts from the heartwood of Amphimas pterocarpoides and Pterocarpus erinaceus. J Chem SO Org 5: 509-510.

11. Boron, Walter F, Boulpaep, Emile L (2009) Medical Physiology ( $2^{\text {nd }}$ Edn.). Saunders Elsevier, Philadelphia, USA, pp. 1016-1017.

12. Brugh VM, Lipshultz LI (2004) Male factor infertility. Medical Clinics of North America 88(2): 367-385.

13. Brunton, Laurence L, Chabner, Bruce A, Knollmann, et al. (2011) Goodman \& Gilmans-pharmacological-basis-of-therapeutics.

14. Deacon JW (2005) Fungal Biology. Wiley.

15. Dramane S, Witabouna KM, Kagoyire K (2010) Evaluation of antimicrobial and free radical scavenging activities of some bioactive taxons from Côte D'ivoire. Eur J Sci Res 40: 307-317.

16. Fafioye 00 (2005) Plants with Piscicidal Activities in Southwestern Nigeria. Journal of Fisheries and Aquatic Sciences 5: 91-97.

17. (1998) Federative Committee on Anatomical Terminology (FCAT).

18. Femi-Ola TO, Ajibade VA, Afolabi A (2008) Chemical composition and termicidal properties of Parkia biglobosa (Jacq) Benth. Journal of Biological Sciences 8(2): 494-497.

19. Field CB, Behrenfeld MJ, Randerson JT, Falkowski P (1998) Primary production of the biosphere: Integrating terrestrial and oceanic components. Science 281(5374): 237-240.

20. Field CB, Behrenfeld MJ, Randerson JT, Falkowski P (1998) Primary production of the biosphere: Integrating terrestrial and oceanic components. Science 281 (5374): 237-240.

21. Gernah DI, Inyang CU, Ezeora NL (2007) Incubation and fermentation of African locust beans (Parkia biglobosa) in production of "dawadawa". Journal of Food Processing and Preservation 31(2): 227-239.

22. Gibo H, Hokama M, Kyoshima K, Kobayashi S (1993) [Arteries to the pituitary]. Nippon Rinsho 51(10): 2550-2554.

23. Gitzendanner MA, Soltis PS, Wong Gane KS, Ruhfel BR, Soltis DE (2018) Plastid phylogenomic analysis of green plants: A billion years of evolutionary history. American Journal of Botany 105(3): 291-301.

24. Hage S, Kienlen-Campard P, Octave JN, Quetin-Leclercq J (2010) In vitro screening on amyloid peptide production of plants used in traditional medicine for cognitive disorders. Journal of Ethnopharmacology 131: 585-591.

25. Heuzé V, Thiollet H, Tran G, Edouard N, Lebas F (2018) African locust bean (Parkia biglobosa \& Parkia filicoidea). Feedipedia, a programme by INRA, CIRAD, AFZ and FAO.

26. Hostettmann K, Marston A, Ndjoko K, Wolfender JL (2000) The Potential of African Medicinal Plants as a Source of Drugs. Current Organic Chemistry 4: 973-1010.

27. Hyrtl J (1880) Onomatologia Anatomica. Geschichte und Kritik der anatomischen Sprache der Gegenwart. Wilhelm Braumüller. K.K. Hofund Universitätsbuchhändler, Wien, Austria.

28. International Anatomical Nomenclature Committee (1966) Nomina Anatomica. Amsterdam: Excerpta Medica Foundation p. 62

29. Jackson C, Clayden S, Reyes-Prieto A (2015) The Glaucophyta: the bluegreen plants in a nutshell. Acta Societatis Botanicorum Poloniae 84(2): 149-165. 
30. Janick J (2008) Parkia biglobosa African Locust Bean. The encyclopedia of fruit \& nuts pp. 395-400.

31. Karou D, Dicko MH, Sanon S, Simpore J, Traore AS (2003) Antimalarial activity of Sida acuta Burm. f. (Malvaceae) and Pterocarpus erinaceus Poir. (Fabaceae). Journal of Ethnopharmacology 89: 291-294.

32. Karou S, Tchacondo T, Tchibozo MD, Abdoul-Rahaman S, Anani K et al. (2011) Ethnobotanical study of medicinal plants used in the management of diabetes mellitus and hypertension in the Central Region of Togo. PharmBiol 49(12): 1286-1297.

33. Knepel W, Homolka L, Vlaskovska M, Nutto D (1984) Stimulation of adrenocorticotropin/beta-endorphin release by synthetic ovine corticotropin-releasing factor in vitro. Enhancement by various vasopressin analogs. Neuroendocrinology 38(5): 344-350.

34. Obeten K, Oria RS, Lawrence EE (2019) Neurotoxicity ofAqueous Extract of Theobroma cacao on the Cerebellum of Adult Wistar Rats. ACTA Scientic neurology 27: 72-75.

35. Koura K, Ganglo JC, Assogbadjo AE, Agbangla C (2011) Ethnic differences in use values and use patterns of Parkia biglobosa in Northern Benin. Journal of Ethnobiology and Ethnomedicine 7: 42.

36. Lewis CT, Short C (1879) A Latin dictionary founded on Andrews' edition of Freund's Latin dictionary. Oxford, Clarendon Press.

37. Lewis LA, McCourt RM (2004) Green algae and the origin of land plants. Am J Bot 91(10): 1535-1556.

38. Liddell HG, Scott R (1940) A Greek-English Lexicon. revised and augmented throughout by Sir Henry Stuart Jones. with the assistance of. Roderick McKenzie. Clarendon Press, Oxford, UK.

39. Lotti F, Maggi M (2014) Ultrasound of the male genital tract in relation to male reproductive health. Human Reproduction Update 21(1): 56-83.

40. Manuel MJ, Garcia E, Vidaurre PJ (2005) An ethnobotanical survey of medicinal plants commercialized in the markets of La Paz and El Alto, Bolivia. Journal of ethnopharmacology 97: 337-350.

41. Elliott AL, David BG (2011) Cranial Fossae. Gray's Clinical Anatomy. Elsevier Health Sciences p. 154.

42. Mann A, Ogbadoyi EO (2012) Evaluation of Medicinal Plants from Nupeland for Their in vivo Antitrypanosomal Activity. American Journal of Biochemistry 2(1): 1- 6 .

43. Margulis L (1974) Five-kingdom classification and the origin and evolution of cells. Evolutionary Biology pp. 45-78.

44. Shlomo M (2011) The Pituitar- (Third Edition). San Diego, CA 921014495, USA: Academic Press is an imprint of Elsevier. pp. 23-25.

45. Millogo-Kone H, Guissou IP, Nacoulma O, Traore AS (2008) Comparative Study of Leaf and Stem Bark Extracts of Parkia Biglobosa Against Enterobacteria. Afr J Tradit Complement Altern Med 5(3): 238-243.

46. Millogo-Kone H, Guissou IP, Nacoulma O, Traore AS (2006) Study of the antibacterial activity of the stem bark and leaf extracts of Parkia biglobosa (jacq.) Benth. on Staphylococcus aureus. African Journal of Traditional, Complementary and Alternative Medicines 3(2): 74-78.

47. Ministry of Health (2011) Document Politique Nationale de la Médecine Traditionnelle au Bénin. Cotonou, Bénin, Ministère de la Santé p. 37.

48. Murray CR, Simmons JG, Allen NB, Byrne ML, Mundy LK, et al. (2016) Associations between dehydroepiandrosterone (DHEA) levels, pituitary volume, and social anxiety in children. Psychoneuroendocrinology 64: 31-39.
49. Muthu C, Ayyanar M, Raja N, Ignacimuthu S (2006) Medicinal plants used be traditional healers in Kancheepuram District of Tamil Nadu, India. J Ethnobio Ethnomed 2: 43.

50. Nelson RJ (2011) An Introduction to Behavioral Endocrinology, (4 $4^{\text {th }}$ Edn.). Sinauer Associates, Inc, Sunderland, MA, USA.

51. Ntui VO, Uyoh EA, Urua IS, Ogbu U, Okpako EC (2012) Regeneration of Parkia biglobosa Benth: An important tree species of Africa. Journal of Microbiology and Biotechnology Research 2(1): 169-177.

52. Olafadehan OA (2011) Changes in haematological and biochemical diagnostic parameters of Red Sokoto goats fed tannin-rich Pterocarpus erinaceus forage diets. Vet. Arhiv 81: 471-483.

53. (2013) Olaniyan A (nd) Locust Bean Products. Non-Wood News-No.10.

54. Ouédraogo N, Sawadogo RW, Tibiri A, Bayet C, Lompo M, et al. (2011) Pharmacological properties and related constituents of stem bark of Pterocarpus erinaceus Poir. (Fabaceae). Asian Pacific Journal of Tropical Medicine pp. 412-420.

55. (2013) Parkia biglobosa (nd) Protabase.

56. Pinkhof H (1923) Vertalend en verklarend woordenboek van uitheemsche geneeskundige termen. Haarlem: De Erven F. Bohn.

57. Sherwood RA, Thomas PS (1977) The Vertebrate Body. Holt-Saunders International, Philadelphia, PA, USA, pp. 549-550.

58. Salawu OA, Aliyu M, Tijani AY (2008) Haematological studies on the ethanolic stem bark extract of Pterocarpus erinaceus poir (fabaceae). African Journal of Biotechnology 7(9): 1212-1215.

59. Patricia SB, Raven JA, Pisani D, Knoll AH (2017) Early photosynthetic eukaryotes inhabited low-salinity habitats. Proceedings of the National Academy of Sciences. 114(37): E7737-E7745.

60. Schreger $\mathrm{CH}$ Th (1805) Species Information-Parkia biglobosa. (n.d.) Agroforestry Tree Database.

61. Teklehaimanot Z (2004) Exploiting the potential of indigenous agroforestry trees: Parkia biglobosa and Vitellaria paradoxa in subSaharan Africa. Agroforestry Systems 61: 207-220.

62. Guyton AC, Hall JE Textbook of Medical Physiology. Elsevier Saunders.

63. Thiombiano DN, Lamien N, Dibong DS, Boussim IJ, Belem B (2012) The role of woody species in managing food shortage in Burkina Faso. Sécheresse 23(2): 86-93.

64. Traoré M, Baldé M, Oularé K, Magassouba F, Diakité I, et al. (2013) Ethnobotanical survey on medicinal plants used by Guinean traditional healers in the treatment of malaria. J Ethnopharmacol 150(3): 11451153

65. Triepel H (1927) Die anatomischen Namen. Ihre Ableitung und Aussprache. Anhang: Biographische Notizen. (Elfte Auflage). München: Verlag J.F. Bergmann.

66. Uyovbisere EO, Elemo KA (2002) Effect of tree foliage of locust bean (Parkia biglobosa) and neem (Azadirachta indica) on soil fertility and productivity of maize in a savanna alfisol. Nutrient Cycling in Agroecosystems 62(2): 115-122

67. Van den Hoek C, Mann DG, Jahns HM (1995) Algae: An Introduction to Phycology. pp. 343, 350, 392, 413, 425, 439, \& 448 (Cambridge: Cambridge University Press)

68. Wells MJ, Wells J (1969) Pituitary Analogue in the Octopus. Nature 222(5190): 293-294

69. (2003) World Health Organization. Traditional Medicine. 


\section{ISSN: 2574-1241}

DOI: 10.26717/BJSTR.2020.29.004837

Kebe E Obeten. Biomed J Sci \& Tech Res

(C) This work is licensed under Creative

Submission Link: https://biomedres.us/submit-manuscript.php

$\begin{array}{ll}\text { BIOMEDICAL } & \text { Assets of Publishing with us } \\ \text { RESEARCHES } & \text { - Global archiving of articles } \\ \text { - Immediate, unrestricted online access } \\ \end{array}$

